\title{
Mediation of detention trauma via perceived locus of control
}

\author{
Adrian Keith Perkel \\ Department of Psychology, University of the Western Cape, Private Bag X17, Bellville 7535, \\ Republic of South Africa
}

Received August 1989; accepted May 1990

\begin{abstract}
Political detention in South Africa has been documented to contain conditions inherently detrimental to psychological health. Reports indicate high levels of stress reponses associated with conditions of solitary confinement, and physical and psychological abuse - particularly in the form of Post-Traumatic Stress Disorder. Amongst the moderating variables that may mediate between detention stress and post-detention trauma is perceived locus of control. In the present study the author aimed to determine post-detention sequelae and the moderating influence of perceived locus of control in this specific context. A PostTraumatic Stress Disorder scale was combined with an Index of Well-being scale and correlated with a Detention Locus of Control scale to assess mediation significance of experienced 'traumatization'. Results indicated a positive correlation with those who are internal in their perceived locus of control suffering reduced post-stress sequelae, compared to those who are more externally oriented. Implications and limitations of the study are discussed with specific reference to therapeutic intervention in the clinical context.
\end{abstract}

Daar bestaan aanduidings in die literatuur dat politieke aanhoudings in Suid-Afrika inherent nadelig is ten opsigte van geestesgesondheid. Melding word gemaak van hoë vlakke van stresreaksie wat die gevolg kan wees van toestande soos eensame aanhouding en fisiese en sielkundige mishandeling — veral in die vorm van Posttraumatiese Stresversteuring. Onder die moderatorveranderlikes wat 'n oorbruggingsfaktor tussen aanhoudingstres en postaanhoudingtrauma kan wees, resorteer waargenome lokus van kontrole. In die onderhawige studie is ' $n$ poging aangewend om die nagevolge van aanhouding vas te stel, sowel as die modererende invloed van waargenome lokus van kontrole in daardie, spesifieke konteks. 'n Posttraumatiese Stresversteuringskaal en 'n Indeks van Welsynskaal is saamgevoeg en met 'n Aanhouding Lokus van Kontroleskaal gekorreleer om die beduidendheid van bemiddeling ten opsigte van die 'traumatisering' wat ervaar is, te evalueer. Die bevindings dui daarop dat die groep met 'n interne waargenome lokus van kontrole ' $n$ afname in stresnagevolge ervaar in teenstelling met dié wat meer ekstern geörienteer is. Die implikasies en beperkings van die studie word bespreek met spesifieke verwysing na terapeutiese intervensies in die kliniese konteks.

Political detention in South Africa, which has become entrenched in the legal system, has a long and controversial history. Since Internal Security Act detentions produce a $1 \%$ conviction rate in the courts [Detainees' Parents Support Committee (hereafter DPSC), 1987], its legitimization by the State in terms of 'criminal' prevention or prosecution remains unconvincing. According to Webster (1985), its intention can be viewed as 'political and intimidatory in intent' (p. 11) and as 'part of the ever-increasing repression and control needed to maintain (South African) society in its present form' (Hayes, 1984, p. 40). Against this background, detention incorporates conditions of virtually complete control by state officials over detainees held in their custody. Closed to independent scrutiny, detention for the purpose of interrogation creates conditions under which abuse may easily flourish (Marcus, 1985).

South African detention incorporates a systematized process of Assault, Invasion and Deprivation (AID) (Perkel, 1988) whereby conditions affecting the detainee are actively manipulated to induce maximum pliability and the effective extraction of information. It is evident that different types of detention exist - of which not all are used to obtain information (see Foster, Davis \& Sandler, 1987, Ch. 3, for a full discussion of the various forms of detention).

Nevertheless, despite the difficulty of generalizing across all froms of political detention, certain common factors do apply. Detention may be arbitrary and indefinite, with a key factor of complete control being exercized by the State apparatus. Denial of access to lawyers, friends, family and even independent medical care is common. Interrogation may be used, and conditions such as solitary confinement may be imposed. The common features of control and the potential for abuse, tend to blur the differences of the various Security provisions.

Such a process has reportedly included indefinite solitary confinement, physical, and psychological abuse (Davis, 1985; DPSC, 1987; Foster \& Sandler, 1985). Each component of the AID process has been widely documented as being potentially pathogenic and inducing of psychological and psychiatric sequelae (see Foster et al., 1987, pp. 57-85, for a detailed review of models of the different components of detention).

Firstly, indefinite confinement itself has been shown in research studies to create more severe emotional reactions than confinement where the termination time was known to subjects (Schultz, 1965; Zuckerman, 1964). This led West (1985) to condemn indefinite confinement, arguing that it could induce the realization of no recourse and complete helplessness in the hands of one's captors.

Secondly, solitary confinement has been equated with sensory and social deprivation conditions (Gendreau, Freedman, Wilde \& Scott, 1972; Zubek, Bayer \& Shepard, 1969), these having been well established in numerous studies to be psychologically pathogenic and detrimental to mental health (e.g. Hocking, 1970; Smith \& Lewty, 1959; Zubek et al., 1969; Zuckerman, 1964). 
Thirdly, physical abuse (allegedly involving, amongst other techniques, electric shocks, beatings, enforced excrcise, suspension, suffocation, etc.) requires no elaboration since the psychological stress effects are well-known.

Fourthly, a variety of psychological techniques have allegedly been employed. These have included the 'goodbad' interrogation style, false and misleading accusations, verbal abuse, threats of violence to self and others, threats of indefinite and prolonged detention, being forced to undress, etc. Such manipulative techniques are designed to induce the realization of helplessness and impotence causing the wearing down of the detainee's resistance. Such interpersonal distortions represent a massive assault on the personality of the detainee and may be regarded as potentially stress inducing.

Outcome studies have tended to confirm the stress potential of detention. Browde (1988), Davis (1985), and DPSC (1987), have reported high numbers of former detainces as evidencing Post-Traumatic Stress Disorder (based on DSMIII criteria, American Psychiatric Association (APA), 1980), as well as other psychological and somatic symptoms and psychiatric disorders found to follow the detention experience. These have included brief reactive psychoses, schizophreniform disorders and major affective disorders (Manson, 1986). Foster et al., (1987), found numerous psychological symptoms occurred following detention. Whilst not formally testing for PTSD, they claim that the symptoms they found were consistent with the disorder.

Despite the lengthy list of symptoms that have been found to follow detention (e.g. Foster \& Sandler, 1985), it is clear that not all detainees suffer the same symptoms to the same degree. Whilst actual experiences in detention may differ, other variables such as personality and social support have been argued to mediate stress effects (Hinkle, 1961; Tyson, 1983). It has been argued, however, that social support is not primary over personality variables such as sense of control, with the positive effect of support being relatively small (Seeman, Sceman \& Sayles, 1985).

One variable that has been well documented as a potential mediator of stress and its effects is perceived locus of control (Johnson \& Sarason, 1978; Kobasa, 1979; Rotter, 1979). According to these findings, those internal in their perceived locus of control have been found to suffer reduced post-stress sequelae compared to those external in their perceived locus of control. Research into locus of control has indicated the significance of the perceived aspect, with the subjective perception of control rather than the objective situation determining mediational significance (Glass \& Singer, 1972). Further, perception of control may vary across different contexts so that an individual internal in one situation may be external in another (Phares, 1978).

Perceived internal locus of control in specific contexts therefore appears to play a significant mediating role in reducing threat and the impact of aversive stimuli (Staub, Tursky \& Schwartz, 1971). The present study was conducted to determine the significance of the perceived locus of control construct in mediating detention trauma. Although objectively relatively out of control in the detention situation, an internally oriented subject may be equipped to withstand detention stress better than an extemally oriented subject. It was predicted that the mediational capacity of this construct would be significant, and that such significance would be useful in informing preand post-detention therapeutic intervention.

\section{Method}

\section{Subjects}

The sample consisted of 33 released detainees, drawn from various geographic areas in South Africa. Their detentions were under various sections, including the State of Emergency (Act 3 of 1953), Scction 29 and Section 50 of the Internal Security Act. Overall, $78,8 \%$ of the sample were held in either Section 29 or under the State of Emergency. Mean age was 26,1 years with a range from 16 years to 54 years. Seven 'white' subjects of whom three were male and four female, three 'coloured' and 'Indian' subjects of whom two were male and one female, and 21 'African' subjects of whom 20 were male and one female, participated. Two subjects were not identified according to race and sex.

Educational levels varied from eight years of primary education to 20 years of primary plus tertiary education, with means for the three groups of $16,1,15,3$ and 10,7 years respectively. Length of detention varied from two days to 338 days with a mean detention length of 85,5 days. All 'African' male subjects alleged assault and/or torture with no 'whites' making similar allegations. Of all subjects, $77,4 \%$ were held in solitary confinement for some or all of their detention. The time held in solitary confinement varied from 6,5 days to 240 days with a mean of 63,9 days. Of those detained, $61,3 \%$ had not been and $38,7 \%$ had been previously detained.

\section{Apparatus}

A Post-Traumatic Stress Disorder scale (PTSD) that assesses symptom intensity based on DSM-III criteria was used (Friedman, Schneiderman, West \& Carson, 1986) together with an Index of Well-being Scale (IWB) (Ochse, 1984) to provide a combined variable of 'traumatization'. The PTSD scale contains 15 items that relate to various PTSD symptoms. The scale is self-administered with each item being rated on a scale as experienced from 1 ('never') to 4 ('often'). This accounts for variation in experienced intensity of different symptoms by different people. The scale was found to have a high internal consistency (Cronbach's alpha of 0,96 ) and validity when compared with clinical psychiatric diagnoses of post-traumatic stress disorder. It was found to discriminate post-traumatic stress from other psychiatric diagnoses $(t=2,81, d f=25, p<$ $0,01)$. For use in the present study, references to Vietnam in the scale (for which the original scale was designed) ${ }^{1}$ were substituted by references to detention without compromising the format of the scale.

The IWB Scale is a self-administered scale that refers to descriptions of present feelings about the subject's life. Rated from 1 to 8 , the scale contains 10 polarizcd adjectives along a negative to positive evaluation of current life state. The scale was shown to be reliable when used with literate South Africans since it was standardized on a multi-racial South African sample. Its internal consistency appeared high (Cronbach alpha of $0,94,0,94$ and 0,93 on blacks, 
English-speaking whites and Afrikaans-speaking whites respectively). Correlations with scores on happiness were satisfactorily high $(0,64,0,76,0,74$ for the respective groups) and with scores of $\operatorname{mood}(0,20,0,33,0,29)$ and social desirability $(0,17,0,24,0,15)$ satisfactorily low thus providing some indication of convergent and discriminant validity (Ochse, 1984). Ochse (1984), argued that it was short enough to include in a questionnaire without placing too much additional demand on subjects. In the present study, the ninth subscale of the IWB scale, based on a question measuring overall life satisfaction, was found to provide no additional information and was therefore dropped from further analysis. An 8-item IWB scale was retained. The scale was scored in the negative direction.

Finally, a Detention Locus of Control scale (DLOC) degeloped by the author was employed. ${ }^{2}$ This scale is based on the format of Rotter's (1966) Internal-External Locus of Control scale which employs a forced-choice format consisting of 29 items. Four of these are fillers aimed to disguise the nature of the test. The DLOC scale consisted of 25 items plus four filler items and was scored in the extemal direction. The scale manifested high internal consistency (Cronbach alpha $=0,82$ ). Correlation with five political items of Rotter's (1966) Internal-external Locus of Control scale was significant $(n=24, r=0,45, p<0,05)$ and higher than correlations with Rotter's whole scale (a generalized measure of locus of control) $(n=24, r=0,18$, $p>0,05)$. This appcared to provide concurrent validity for a context-specific measure of locus of control such as the DLOC scale. All items of the DLOC referred specifically to the detention situation with no general items present as in Rotter's scale. Since the scale was designed to be specific to detention, instructions informed subjects that this was a questionnaire to find out 'the way you felt about different things during your detention'. Examples of scale items included the following:

(a) detention is something I expected

(b) being detained took me completely by surprise

(a) I sometimes laughed inside at the Security Police during interrogation

(b) things were so unexpected during interrogation I didn't really have time to think.

\section{Procedure}

Questionnaires were distributed via various sources: they were handed out to individual detainees; they were handed out to 'contact' people who forwarded them to detainees; organizations such as the Detainees Counselling Services, Detainees Support Committees and church support groups acted as liaison points for administration and collection of questionnaires. All scales were confidentially self-administered and retumed via the distribution sources. Anonymity was maintained.

\section{Results}

Scale breakdown revealed that $93,8 \%$ of subjects reported the presence of at least some PTSD symptomatology. If DSM-III criteria for a clinical diagnosis of PTSD is considered, $75 \%$ of the sample qualified for the diagnosis (excluding four cases with missing data). Criteria for this
Table 1 Pearson correlations for PTSD, IWB, combined PTSD-IWB and DLOC scores

\begin{tabular}{lccc}
\hline & $N$ & $r$ & $p$ \\
\hline PTSD with IWB & 22 & 0,49 & $p<0,05$ \\
PTSD with DLOC & 25 & 0,44 & $p<0,05$ \\
IWB with DLOC & 22 & 0,34 & $p>0,05$ \\
Combined PTSD-IWB with DLOC & 22 & 0,46 & $p<0,05$ \\
\hline
\end{tabular}

Table 2 Multiple regression of locus of control (DLOC), presence or absence of assault, and length in detention as predictors of traumatic response (PTSD)

\begin{tabular}{lccc}
\hline Prediction order & $F$ & $d f$ & $p$ \\
\hline 1. Locus of control (DLOC) & 6,18 & 1,24 & $p<0,05$ \\
2. Assault & 3,38 & 2,23 & $p>0,05$ \\
3. Length & \multicolumn{3}{c}{ Non-significant predictor } \\
\hline
\end{tabular}

diagnosis was based on DSM-III criteria for PTSD (APA, 1980) which requires one symptom from category B (reexperiencing of the trauma), one from category C (emotional numbing and withdrawal), and two from category $D$ (autonomic, dysphoric or cognitive symptoms).

As can be seen in Table 1, Pearson correlations revealed that the PTSD scale correlated with the IWB scale at 0,49 $(n=22, p<0,05)^{3}$. The PTSD scale correlated with the DLOC scale at $0,44(n=25, p<0,05)$. The IWB scale correlated with the DLOC scale at $0,34(n=22, p>0,05)$. In order to combine the PTSD scale and the IWB scale into a single score measuring 'traumatization', which could then be correlated with the DLOC, a MANOVA procedure was employed. This was done to increase the validity of reported traumatic response. A composit variable (traumatization) was developed employing weightings for PTSD and IWB $(0,78$ and 0,35 respectively) derived from the standardized cannonical coefficients for the variables. This correlated significantly with the DLOC scale $(n=22, r=$ $0,46, p<0,05$ ). Higher external locus of control correlated positively with increased traumatization.

The significance of locus of control as a mediational process over other variables such as the severity of conditions was determined. Length of detention and whether assaulted or not were considered. As can be seen in Table 2 , multiple regression analysis revealed that locus of control was the best predictor of post-traumatic stress $(F=6,18$, $d f=1,24, p<0,05)$ with the DLOC correlating significantly with the PTSD scale ( $n=26, r=0,45, p<0,05$ ). Assault was the second best predictor but was not statistically significant $(F=3,38, d f=2,23, p>0,05)$. Longer detention periods did appear to be correlated with higher stress response but this was also not significant $(n=26$, $r=0,13, p>0,05)$.

\section{Discussion}

Locus of control has been widely demonstrated to play a potentially mediating role between environmental stressors and individual psychological response. As a construct, locus of control is broadly descriptive of a particular mode of 
functioning and does not refer to a trait that is typological or unchangable in form (Phares, 1978; Rotter, 1975). Locus of control is variable and may differ across different contexts, depending on prior experience, expectations, preparation, and interpretation of the context. People extemal in one situation may be internal in another. Accordingly, testing the mediating capacity of this construct in detention required the construction of a scale specific to this area. The DLOC was constructed and validated to fulfil this need according to the dictates of the theory (Rotter, 1979).

PTSD remains a useful measure of stress response known to follow stressful events. Accordingly, employing this instrument as a measure of detention stress enabled stress response specific to detention to be measured. Given the potential for defensive responding in this sample, an Index of Well-being measure was employed to increase the reliability of a 'traumatization' variable.

It appears feasible that social desirability influences may have led to over-reporting of symtomatology rather than defensive reporting. This was considered unlikely, however, for the following reasons: firstly, clinical work with released detainees has tended to find that acknowledging symptoms is regarded as acknowledging 'weakness'. This may raise questions in political and community organizations regarding the detainees political commitment and 'trustworthiness'. The Detention Treatment Team (DTT) in Cape Town, for example, have reported that 'many activists do not admit that they have been affected because they feel that it will show weakness' (Detention Action Committee, 1985, p. 4). Findings of this nature have also been reported in other countries where admitting symptomatology may imply a stigma. Symptoms are therefore denied for years without motivation for treatment (Somnier \& Genefke, 1986).

Secondly, analysis revealed a narrow difference between the correlations of the PTSD and DLOC scales, and the combined PTSD-IWB and DLOC scales $(r=0,44$ and 0,46 respectively). The addition of the IWB scale therefore did not appear to substantially increase the usefulness of a measure of degree of traumatization. Nevertheless, it did appear to reflect that reporting of post-traumatic symptomatology and sense of well-being may have been reasonably accurate. The significant correlation between the two variables $(r=0,49)$ appears to add support to this assumption. Since the two measures provide both subjective and objective indicators of traumatic stress, these findings appear to contradict an expected under-reporting (defensive bias), or over-reporting (social desirability bias that may have arisen, despite the self-administered anonymity and confidentiality, due to contamination through the distribution procedure).

The correlation between 'traumatization' and locus of control in the detention-specific situation $(0,46)$, was considered satisfactory given the high number of potentially confounding variables. Severity of conditions, for example, may override the significance of mediational processes such as locus of control (see Foster et al., 1987). Two indices of severity of conditions, length of detention and presence of assault, were therefore compared with locus of control as a predictor of traumatic symptoms. Locus of control was the best predictor of post-traumatic symptoms over assault and length of detention. It was also the only significant correlation.

The implication of this finding appears to provide positive support for the hypothesis that perceived internal locus of control may mediate the stress effects in detention. Those external in their perceived locus of control experience greater psychological sequclac to the profound stress of detention and the process of AID.

Kobasa, Maddi \& Courington (1981), have argued for a personality construct that mediates stressful events. This they term 'hardiness'. Hardy persons, they argue, use optimistic cognitive appraisal to evaluate events as interesting despite their stressfulness and as under personal influence. In these ways, hardy persons transform stressful events into less stressful forms. By contrast, individuals low in hardiness perceive themselves and their environment to be boring, meaningless, threatening and see themselves as powerless. The latter appears to be correlated with higher subjective stress and greater susceptibility to breakdown into illness as a consequence (Kobasa, 1979).

Whilst hardiness includes concepts such as committment to ones beliefs, and challenge rather than stability in a changing environment, control appears to remain a major component of the hardy personality. Both commitment and challenge involve cognitive re-appraisal which represent qualities of an internal locus of control. Locus of control, therefore, appears to be central in mediational processes and in the attributes of the 'hardy' personality. Funk and Kent Houston (1987), have argued on the basis of research into the construct, that the subscales do not define the dimensions hypothesized to underlie the hardiness construct. In addition, it has been argued that 'hardiness' should not be considered a unitary construct and that research into health outcome be based on the independent contributions of, amongst others, control (Hull, Van Treuren \& Vimelli, 1987). Since locus of control is context-specific (Phares, 1978) and modifiable, it may be viewed more usefully as a mediational process than as a typological construct (Phares, 1978; Rotter, 1975) as implied by the notion of a 'hardy' personality.

The most important implications of the present study may be drawn from the modifiable nature of locus of control. Since it is not typological and unchangable in form and may vary across different contexts, its mediational capacity may be usefully employed to reduce the stress effects of the detention situation. A tentative possibility is that people whose orientation leans in the externa' lirection, may benefit from therapeutic intervention that assists in reorienting their locus of control 1 rceptior in an internal direction. This basis would info_n a ther apeutic process that may be more effective in reducing post-detention sequelae.

Further, people who face a high risk of being detained incommunicado for political or other reasons, may also benefit from intervention which aims to re-orientate their perceived locus of control in an internal direction. Such 'preventive' intervention may go some way towards ameliorating the difficult task faced by clinicians in treating unprepared people following exposure to detention trauma. ${ }^{4}$ Such clinical application remains speculative, however, 
since empirical investigation into therapeutic inclusion of these concepts is lacking. Further investigation is required in this regard.

\section{Conclusion}

Perceived locus of control was found in the present study to mediate the stress effects of the AID process inherent to South African detention. Since an internal locus appears to be correlated with reduced detention sequelae, this construct may be modified therapeutically to improve treatment strategies with this population. Given the theoretical nature of this study, definitive conclusions regarding treatment efficacy remain speculative. Further research remains necessary, therefore, to determine whether clinical application of perceived locus of control orientation warrants therapeutic inclusion. The implications of this study appear to provide support for doing so.

\section{Acknowledgements}

Particular thanks are expressed to Terri Broll and to Bruce Faulds, both of the Department of Psychology, University of Natal, Pietermaritzburg, for their ready assistance; to Anna Strebel and Rajen Govender, both of the Department of Psychology, University of the Western Cape, for their assistance; and to Don Foster of the Department of Psychology, University of Cape Town for comments on earlier drafts of this article. Financial contribution in the form of a Human Sciences Research Council bursary is gratefully acknowledged.

\section{Notes}

1. The original scale was developed for use with Vietnam veterans and hence contained references to Vietnam. These were substituted for references to detention. For example, 'How often do you experience recurrent and intrusive memories of your experience(s) in Vietnam?' was changed to read 'How often do you experience recurrent and intrusive memories of your experience(s) in detention?'

2. Further information on construction, reliability and items can be found in Pertel, A and Govender, R. (1990). Development and testing of a scale to measure locus of control in South African political detainees. Psychological Reports, 67 , 387-395.

3. Variability of the $n$ value arose due to missing or incomplete data with some cases on specific items.

4. Discussion on intervention strategies based on this research forms the basis of another paper - see Perkel, A. (1990) Psychotherapy with detainees: A theoretical basis. Psychology in Society, 13, 4-16.

\section{References}

American Psychiatric Association (1980). Diagnostic and statistical manual of mental disorders (3rd ed.) Washington D.C.: American Psychiatric Association.

Browde, S. (1988). The treatment of detainees, In C.P. Owen (Ed.), Proceeding of the 1987 National Medical and Dental Association (NAMDA) Annual Conference: Towards a national health service. Cape Town: National Medical and Dental Association.

Davis, P. (1985). Medical problems of detainees: A review of 21 ex-detainees seen in the past 2 years in Johannesburg. In A.B. Zwi \& L.D. Saunders (Eds), Proceedings of the NAMDA Conference '85: Towards health care for all (pp. 15-18). Johannesburg: National Medical and Dental Association.

Detainees' Parents Support Committee (1987). Report 1987. Johannesburg: Detainees Parents' Support Committee.

Detention Action Committee (1985, April). ADAC NEWS. Salt River: ADAC.

Foster, D., Davis, D. \& Sandler, D. (1987). Detention and torture in South Africa: Psychological, legal, and historical studies. Cape Town: David Phillip.

Foster, D. \& Sandler, D. (1985). A study of detention and torture in South Africa: Preliminary report. Cape Town: Institute of Criminology, University of Cape Town.

Friedman, M.J., Schneiderman C.K., West, A.N. \& Carson, J.A. (1986). Measurement of combat exposure, posttraumatic stress disorder, and life stress among Vietnam combat veterans. American Journal of Psychiatry, 143, 537-539.

Funk, S.C. \& Kent Houston, B. (1987). A critical analysis of the hardiness scale's validity and utility. Journal of Personality and Social Psychology, 53, 572-578.

Gendreau, P., Freedman, Wilde, G.J.S. \& Scott, G.D. (1972). Changes in EEG alpha frequency and evoked response latency during solitary confinement. Journal of Abnormal Psychology, 79, 54-59.

Glass, D. \& Singer, J.E. (1972). Urban stress: Experiments on noise and social stressors. New York: Academic.

Hayes, G. (1984). MASA and the politics of detention. Work in Progress, 20, 40-45.

Hinkle, L.E. Jr. (1961). The physiological state of the interrogation subject as it affects brain function. In A.D. Biderman \& H. Zimmer (Eds), The manipulation of human behaviors (pp. 19-50). New York: Wiley.

Hocking, F. (1970). Extreme environmental stress and its significance for psychopathology. American Journal for Psychotherapy, 24, 4-26.

Hull, J.G., Van Treuren, R.R. \& Virnelli, S. (1987). Hardiness and health: A critique and alternative approach. Journal of Personality and Social Psychology, 53, 518-530.

Johnson, J.H. \& Sarason, I.G. (1978). Life stress, depression and anxiety: Internal-external control as a moderator variable. Journal of Psychosomatic Research, 22, 205-208.

Kobasa, S.C. (1979). Stressful life events, personality, and health: An inquiry into hardiness. Journal of Personality and Social Psychology, 37, 1-11.

Kobasa, S.C., Maddi, S.R. \& Courington, S. (1981). Personality and constitution as mediators in the stress illness relationship. Journal of Health and Social Behaviour, 22, 368-378.

Manson, S. (1986). Detention rehabilitation. In Organisation for Appropriate Social Services in South Africa, Apartheid and mental health: OASSSA National Conference 17-18 May 1986 (pp. 67-73). Johannesburg: Organisation for Appropriate Social Services in South Africa.

Marcus, G. (1985). Legal aspects of the health care of detainees. In A.B. Zwi \& L.D. Saunders (Eds), Proceedings of the NAMDA Conference '85: Towards health care for all (pp. 29-40). Johannesburg: National Medical and Dental Association.

Ochse, R. (1984). Measuring global life-satisfaction in South African subjects. South African Journal of Psychology, 14, 60-63. 
Perkel, A. (1988). Perceived locus of control as a correlate of traumatisation during detention - with implications for therapeutic intervention. Unpublished M.A. (Clinical Psychology) thesis, University of Natal, Pietermarizburg.

Phares, E.J. (1978). Locus of control. In H. London \& J.E. Exner Jr. (Eds), Dimensions of personality (pp. 263-304). New York: Wiley-Interscience.

Rotter, J.B. (1966). Generalized expectancies for internal versus external control of reinforcement. Psychological Monographs: General and Applied, 80, 1-28.

Rotter, J.B. (1975). Some problems and misconceptions related to the construct of intemal versus external control of reinforcement. Journal of Consulting and Clinical Psychology, 43, 56-67.

Rotter, J.B. (1979). Comments on section IV: Individual differences and perceived control. In L.C. Perlmutter \& R. Monty (Eds), Choice and perceived control (pp. 263-269). New Jersey: Lawrence Erlbaum.

Schultz, D.P. (1965). Sensory restriction: Effect on behavior. New York: Academic.

Seeman, M., Seeman, T. \& Sayles, M. (1985). Social networks and health status: A longitudinal analysis. Social Psychology Quarterly, 48, 237-248.
Smith, S. \& Lewty, W. (1959). Perceptual isolation being a silent room. Lancet, 2, 342-345.

Somnier, F.E. \& Genefke, I.K. (1986). Psychotherapy for victims of torture. British Journal of Psychiatry, 149, 323-329.

Staub, E., Tursky, B. \& Schwartz, G.E. (1971). Self-control and predictability: Their effects on reactions to aversive stimulation. Journal of Personality and Social Psychology, 18, 157-162.

Tyson, G.A. (1983). Stress and detention. SA Medical Journal, 64, 858-859.

Webster, D. (1985). Detentions in 1984. In A.B. Zwi \& L.D. Saunders (Eds), Proceedings of the NAMDA Conference ' 85 : Towards health care for all (pp. 11-14). Johannesburg: National Medical and Dental Association.

West, L.J. (1985). Effects of isolation on the evidence of detainecs. In A.D. Bell \& R.D.A. Mackie (Eds), Detention and securily legislation in South Africa (pp. 69-80). Durban: University of Natal.

Zubck, J.P., Bayer, L. \& Shepard, J.M. (1969). Relative effects of prolonged social isolation and confinement: Behavioral and EEG changes. Journal of Abnormal Psychology, 74, 625-631.

Zuckerman, M. (1964). Perceptual isolation as a stuess situation: A review. Archives of General Psychiatry, 11, 255-276. 